\title{
'New Morning? Irish Labour Law Post-Austerity
}

This is an earlier draft of an article published in: (2016) 39(1) Dublin University Law Journal

This special edition of the DULJ collects papers from a symposium organised at Trinity College Dublin in February 2016 on 'Forging Future Labour Law Agendas in Europe'

Michael Doherty*

- Professor of Law, Department of Law, Maynooth University, Co. Kildare, Ireland. Email: 


\section{Introduction}

This article charts the trajectory of Irish labour law from 2007, at the point at which the economic, political and social crisis that has engulfed Europe and much of the Western world for much of the past decade, began to manifest, through the years of "austerity" and the European Union-International Monetary Fund (EU-IMF) programme of financial assistance. The article reflects on the position now, as Ireland, and Europe, slowly emerges from austerity. It looks at the future labour law agendas that might be forged in Ireland, within the context of developments in EU law. The article looks, first, at the features of the Irish labour law model (from the perspective of individual and collective rights) that had developed, when the global economic recession hit in 2007, traces the changes that occurred during the "crisis years" until 2014, and looks at a series of recent legislative and policy developments that have taken root in 2015. The developments in Ireland, in terms of the development of (individual and collective) labour law protections, and the enforcement and vindication of worker rights, are set in the context of European Union level developments relating to worker rights, socio-economic governance, and employment standard-setting. 


\section{Heaven? (2007)}

The Irish system of employment relations, which is derived from that of the United Kingdom (UK), has traditionally been classified as 'voluntarist', where the preference is for joint trade union and employer regulation of employment relations and the relative absence of legal intervention. ${ }^{1}$ In such a model, the primary role of the State is to provide a supportive framework for voluntary collective bargaining, which should be the principal means by which the employment relationship is regulated. Statutory intervention in the relationship, by contrast, should be avoided; "principal purpose of labour law is to regulate, support and restrain the power of management and organised labour". ${ }^{2}$ By 2007, many commentators had concluded that it had been inaccurate for some time to describe the Irish employment relations system as voluntarist, due to the decline in trade union density ${ }^{3}$ and voluntary collective bargaining, and the parallel expansion in individual employment rights (many derived from EU legislative action), which had resulted in a transition from a bargainingbased employment relations system to a rights-based system. ${ }^{4}$

\section{Individual Rights}

What is clear is that Irish legislation in terms of individual employment rights has very much been based on a "floor of rights" model. Ireland almost never takes the option, for example, of "gold-plating" EU labour market Directives, and, indeed, often lobbies (frequently with the UK) to water-down EU measures impacting on the labour

\footnotetext{
${ }^{1}$ See Paul Teague,"Deliberative Governance and EU Social Policy" (2001) 7(1) European Journal of Industrial Relations 7.

${ }^{2}$ Otto Kahn-Freund, Labour and the Law (Stevens, 1977), at 4.

${ }^{3}$ Then standing at approximately $35 \%$; in the private sector, the figure was approximately $20 \%$; Brian Sheehan, "Union Density Drops 10\% in a Decade" (2005) 35 IRN 12.

${ }^{4}$ Paul Teague, "New Developments in Employment Dispute Resolution" (2005) 4 LRC Rev 5.
} 
market. ${ }^{5}$ Ireland generally places highly in rankings of countries by organisations such as the World Bank, IMF and Organisation for Economic Co-operation and Development (OECD) when "Employment Protection Legislation" (EPL) scores are allocated (where countries fare worse if their labour law systems guarantee more rights or greater protections to workers). To take one example, in 2007, Ireland placed $5^{\text {th }}$ in the OECD's "Strictness of employment protection - individual and collective dismissals (regular contracts)" ranking ("pipped to the post" by its Anglophone cousins, in ascending order, the UK, Australia, Canada, and the USA). ${ }^{6}$

The expansion in individual employment rights protection (between 1990 and 2010, 28 major labour law Acts were passed in Ireland) ${ }^{7}$ led to an increasing focus on individual dispute resolution mechanisms. The elaborate, but patchwork, system of employment tribunals in existence in Ireland became the subject of sustained criticism, with the objectives behind setting up specialist employment tribunals, to provide a flexible, speedy and relatively informal means of resolving workplace disputes, being increasingly unmet. ${ }^{8}$ Declining trade union density, and the weak legal protections for collective bargaining (see below), meant that disputes were becoming more and more individualised, with aggrieved workers either navigating the complex employment tribunal system alone, or, frequently, turning to legal (rather

\footnotetext{
${ }^{5}$ See, for example, the tortuous road to the final adoption of Directive 2002/14/EC of the European Parliament and of the Council of 11 March 2002 establishing a general framework for informing and consulting employees in the European Community OJ L80/02; Pascale Lorber, "Worker Participation and Industrial Democracy: Strengthening Information and Consultation", in Ales et al eds, Fundamental Social Rights in Europe: Challenges and Opportunities? (Intersentia, 2009); Michael Doherty, "Hard Law, Soft Edge? Information, Consultation and Partnership" (2008) 30(6) Employee Relations 603.

${ }^{6} \mathrm{https}$ ://stats.oecd.org/Index.aspx?DataSetCode=EPL OV (accessed June 2 2016).

${ }^{7}$ Michael Doherty, 'Labour Law' in Schweppe and Mohr eds 30 Years of Irish Legal Scholarship. (Round Hall, 2012).

${ }^{8}$ Paul Teague and Damian Thomas, Employment Dispute Resolution and Standard Setting in the Republic of Ireland (LRC, 2008).
} 
than trade union) representation, for which no legal aid was available, and in respect of disputes for which costs were (in the absence of vexatious conduct) not awarded. ${ }^{9}$

In the national, tri-partite, social pact (discussed further below) of 2006, a significant section focused on the issue of compliance with employment law. The commitments agreed by the social partners (which were published in legislative form in the never-enacted Employment Law (Compliance) Bill 2008) were driven by the outcome of a series of extremely high-profile employment law disputes involving posted, and migrant, workers. ${ }^{10}$ The key elements of the Bill were to establish a new labour inspection body, the National Employment Rights Authority (NERA), with enhanced powers of inspection, and powers to co-operate with other state agencies in order to further compliance with employment regulation. NERA was, in fact, established in 2007 (notwithstanding the non-enactment of the 2008 Bill). The Bill also proposed more than 20 new criminal offences relating to, and enhanced penalties for, breaches of employment law. It also proposed a new statutory duty on all parties to a dispute to attempt, where at all possible, to resolve it at workplace level. ${ }^{11}$

\section{Collective Rights}

In terms of collective employment rights, Ireland provides notably weak legal protection for collective bargaining, and collective worker representation. The Irish Constitution protects the right of freedom of association, but trade unions in Ireland enjoy no rights to be recognised for bargaining purposes by an employer. Thus,

\footnotetext{
${ }^{9}$ Brenda Daly and Michael Doherty, Principles of Irish Employment Law (Clarus Press, 2010), at chapter 2.

${ }^{10}$ Notably involving Irish Ferries and Gama; see Torben Krings, "A Race to the Bottom? Trade Unions, EU Enlargement and the Free Movement of Labour" (2009) 15(2) European Journal of Industrial Relations 49. ${ }^{11}$ Employment Law Compliance Bill 2008, section 33.
} 
while employees are free to join a trade union, they cannot insist their employer negotiate with that union regarding their pay and conditions. ${ }^{12}$ Collective bargaining in Ireland, therefore, is seen as normative; collective agreements are usually not legally enforceable, as they do not generally intend to create legal relations. ${ }^{13}$ However, in 2007, some important qualifications to this position existed.

\section{(i) Sectoral Standards}

Collective agreements could be given legal effect if such agreements were registered with the Labour Court (known as "Registered Employment Agreements"; REAs). ${ }^{14}$ REAs at the sectoral level, made between the main employer body representing employers, and the trade unions representing workers, in the relevant sector, were traditionally the most significant (particularly in the construction sector) and had erga omnes effect. In addition, Joint Labour Committees (JLCs) provided for the fixing of minimum rates of pay and the regulation of employment in certain sectors where there was little or no collective bargaining and where significant numbers of vulnerable workers were employed (e.g. retail, catering, and hotels). ${ }^{15}$ JLCs comprised of an independent chairperson, appointed by the Minister, and representative members of workers and employers. They proposed "Employment

\footnotetext{
12 This has been established in many cases before the Irish courts; see, for example, the decision of the Irish Supreme Court in Ryanair v Labour Court [2007] 4 IR 199.

${ }^{13}$ See, for example, Holland $v$ Athlone IT [2011] IEHC 414, where the Irish High Court held that the Public Service Agreement 2010-2014, made between public sector unions and management, could not be taken to have created enforceable legal rights which are justiciable in law at the hands of an individual public sector employee. The Court held that the language used in the agreement applied in the political and industrial relations sphere, but not the legal sphere, and that the parties had never intended to create legal rights. 14 Part III of the Industrial Relations Act 1946 (as amended). Note that, despite its name, the Irish Labour Court is not part of the regular court system, but is a statutory employment tribunal, comprised of representatives of unions and employers, and chaired by a government nominee. The Labour Court, depending on the nature of the dispute before it, may grant legally binding 'determinations', or 'recommendations', which are not legally binding.

15 Part IV of the Industrial Relations Act 1946 (as amended).
} 
Regulation Orders" (EROs), which, when confirmed by the Labour Court, set legally binding minimum wages and conditions of employment for workers in the sectors covered. In 2007, EROs provided: for minimum sectoral rates of pay in excess of the national minimum wage; for sectoral pay scales, based on length of service and skill level; for sectoral overtime payments and premium payments to those required to work on Sundays; and for other benefits for employees in the relevant sectors that were not given by general labour legislation (most notably, a right to sick pay). ${ }^{16}$ Thus, both the REA and JLC systems represented a significant departure from the Irish (indeed, Anglo-American) norm, ${ }^{17}$ in that terms and conditions of employment were not settled through direct contractual negotiations between the employer and its workers, but rather, employment standards were set, and applied, not only for employers that recognised trade unions and union members, but also for employers which did not engage in collective bargaining.

\section{(ii) Trade Union Recognition}

Ireland has never had a statutory union recognition procedure (SRP), such as that introduced by the UK government in Schedule A1 of the Employment Relations Act 1999. ${ }^{18}$ Instead, in 2001, the Irish government introduced what has been termed 'right to bargain' legislation; the Industrial Relations (Amendment) Acts 2001-2004. ${ }^{19}$ This provided, not for union recognition, but for a range of procedures to allow unions, with members in organisations where employers did not recognise unions for

\footnotetext{
${ }^{16}$ Michael Doherty, "Battered and Fried? Regulation of Working Conditions and Wage-Setting after the John Grace Decision" (2013) 35 DULJ 97.

${ }^{17}$ Alan Bogg, The Democratic Aspects of Trade Union Recognition (Hart, 2009).

${ }^{18}$ Ruth Dukes, “The Statutory Recognition Procedure 1999: No Bias in Favour of Recognition?” (2008) 37(2) ILJ 236.

${ }^{19}$ Anthony Kerr, The Trade Union and Industrial Relations Acts (5th ed, Round Hall, 2015).
} 
bargaining purposes, to seek to have specific disputes with regard to pay, terms and conditions of employment and dispute resolution procedures addressed, by means, ultimately, of a legally binding determination of the Labour Court. This clearly did not amount to "collective bargaining", ${ }^{20}$ but did enable trade unions a mechanism to "demonstrate" effectiveness to both members and, crucially, non-members at organisational level, and did ensure the "shadow of the law" hung over recalcitrant employers, providing an incentive to engage in voluntary collective bargaining. ${ }^{21}$

\section{(iii) National Bargaining and the Public Sector}

It should also be noted that voluntary collective bargaining at national level was an important feature of labour relations in Ireland between 1987 and 2007. During this period, a series of social pacts was concluded between the social partners; the State; the unions (represented by the only trade union confederation, the Irish Congress of Trade Unions- ICTU); and the employers (represented primarily by the main employers' association, the Irish Business and Employers ConfederationIBEC- but also by sector specific groups, like the Construction Industry Federation). ${ }^{22}$ The social pacts each ran for three years, focusing on issues of pay (for the public sector and the unionised private sector), tax reform and a range of other socioeconomic issues. ${ }^{23}$ Thus, the Irish trade union movement and the main employer

\footnotetext{
${ }^{20}$ Section 5(2) of the 2001 Act explicitly stated that the Labour Court "shall not provide for arrangements for collective bargaining".

${ }^{21}$ Michael Doherty, "Representation, Bargaining and the Law: Where Next For the Unions?" (2009) 0(4) NILQ 383.

${ }^{22}$ All of the agreements can be accessed at http://www.taoiseach.gov.ie/eng/Publications/Publications Archive/ (accessed June 2 2016).

${ }^{23}$ William K. Roche, "Social Partnership in Ireland and New Social Pacts" (2007) 46(3) Industrial Relations 395.
} 
representative groups had a strongly institutionalised role in national socio-economic governance. The bargaining and implementation processes under the "social partnership" process were voluntary, with unilateral withdrawal by any party possible at any time. However, a number of key labour law measures were agreed, which were then progressed through the normal legislative process; for example, legislation on a national minimum wage,${ }^{24}$ and throughout the period, agreements between public sector management and trade unions on public sector pay, reform and management measures were agreed and, almost without exception, implemented. ${ }^{25}$ The social partnership agreements also contained industrial peace clauses, and an elaborate institutional structure for the resolution of disputes relating to their interpretation or implementation.

\section{Before the Storm}

The period of rapid growth in wealth creation and employment that occurred in Ireland between 1997 and 2007, therefore, was founded on a labour relations model with a number of constituent parts. First, workers were gaining access to an increasing volume of employment protection legislative measures. ${ }^{26}$ In order to access protections, in the context of declining trade union workplace presence, workers did, however, have to navigate the complexity, delays, and costs associated with the individualised employment tribunal system. Secondly, there was a strong focus on the need for greater compliance with employment law, with the proposed

\footnotetext{
24 The National Minimum Wage Act 2000.

${ }^{25}$ Lucio Baccaro and Marco Simoni, "Centralised Wage Bargaining and the 'Celtic Tiger' Phenomenon" (2007) 46(3) Industrial Relations 426.

${ }^{26}$ Examples include the introduction of a national minimum wage (National Minimum Wage Act 2000), protections for part-time workers (Protection of Employees (Part-Time Work) Act 2001), and fixed-term workers (Protection of Employees (Fixed-Term Work) Act 2003), and new health and safety laws (Safety, Health and Welfare at Work Act 2005).
} 
solution residing in greater powers being allocated to the State's labour inspectorate, and greater reliance being placed on criminal sanctions for employment law breaches. Thirdly, most private sector employers were completely free to decide whether or not to negotiate with trade unions. However, there was "right to bargain" legislation, which provided some scope for unions to force uncooperative employers to engage with demands around pay, and other terms and conditions of employment. Fourthly, in a number of sectors (notably construction, retail, catering, and hotels) sectoral collective agreements, or terms and conditions of employment agreed by sectoral labour committees, were extended erga omnes. Finally, social partner agreement, as set out in the various social pacts, was fundamental to setting terms and conditions of employment in the public sector and in the unionised private sector. ${ }^{27}$ Thus, at the onset of the crisis, the Irish Anglo-Saxon model was somewhat precariously balanced. There was undoubtedly a move towards 'juridification' of (increasingly individualised) labour disputes, but the model still maintained a role for collective negotiation, and substantial social partner involvement in employment standard-setting, and monitoring.

\footnotetext{
${ }^{27}$ Indeed, it should be noted that there have been suggestions that the pay rates set down in the national agreements also acted as a benchmark for non-union firms; David Collings et al, "Between Boston and Berlin: American MNCs and the Shifting Contours of Industrial Relations in Ireland" (2008) 19 International Journal of Human Resource Management 242.
} 


\section{Hell? (2008-2014)}

The extent of Ireland's economic and social collapse from 2008 is by now welldocumented and understood. ${ }^{28}$ The country's Gross Domestic Product collapsed, unemployment levels tripled in just four years, there was a rapid deterioration in the public finances, a collapse in the housing market and construction sector, and a liquidity crisis for the banking system. In 2008 , the State (endorsed by the EU) decided to guarantee all banking debt, effectively socialising the crippling debts of the national financial institutions. In November 2010, the Irish government accepted the terms of an IMF-EU rescue package, totalling approximately $€ 85$ billion. The government agreed, as a precondition for receiving bail-out funds, to the adoption of an austerity program, the exact terms of which were provided for in the December 1 2010 Memorandum of Understanding (MoU) signed with the 'Troika' of the European Central Bank, the European Commission and the IMF. ${ }^{29}$

\section{Individual Rights}

In the midst of such tumult, particularly the elements driven by external forces (economic and political), what is remarkable is the relative stability of the labour relations model. In terms of individual employment rights, the floor of rights remained, largely untouched. A cut to the minimum wage level in late-2010 was quickly reversed in early-2011. The Protection of Employment (Temporary Agency

\footnotetext{
${ }^{28}$ See, for example, Kevin O' Kelly, “The End of Social Partnership in Ireland?” (2010) 16(3 Transfer: European Review of Labour and Research 425.

${ }^{29}$ Michael Doherty, "It Must Have Been Love...But It's Over Now. The Crisis and Collapse of Social Partnership in Ireland" (2011) 17(3) Transfer: European Review of Labour and Research 371. The $2010 \mathrm{MoU}$ and all subsequent documents relating to Ireland's bail-out are available at http://www.finance.gov.ie/what-we-do/eu-international/irelands-programme-eu-imf-programme (accessed June 2 2016).
} 
Work) Act 2012, transposing the Agency Workers Directive, ${ }^{30}$ was passed granting temporary agency workers equal treatment rights in respect of the duration of working time, rest periods, night work, annual leave and public holidays, and pay. Existing legislative protections continued as before. Ireland slipped in the OECD's 2014 "Strictness of employment protection - individual and collective dismissals (regular contracts)" ranking; but marginally from $5^{\text {th }}$ to $6^{\text {th }}$ place. ${ }^{31}$

The system of individual dispute resolution mechanisms also remained untouched. However, with the numbers of claims for redundancy and unfair dismissal rising in parallel with falling employment levels and wide-scale corporate restructuring, and in the context of judicial concern around the "human rights implications" of the complexity, delays, and costs associated with the system, ${ }^{32}$ the Government did publish a blueprint for reform (see, further, below). ${ }^{33}$ In the context of the crisis, the focus on compliance arguably diminished, as employers, workers, and unions focused on job protection, and as the numbers of posted, and migrant, workers in the labour force declined. NERA (the new labour inspectorate) did, however, actively pursue its mandate, which included criminal prosecution of noncompliant employers. ${ }^{34}$

\section{Collective Rights}

\footnotetext{
${ }^{30}$ Directive 2008/104/EC of the European Parliament and of the Council of 19 November 2008 on temporary agency work, OJ L327/9.

${ }^{31} \mathrm{https}$ ://stats.oecd.org/Index.aspx?DataSetCode=EPL_OV (accessed June 2 2016).

32 JVC Europe Ltd v Panisi [2011] IEHC 279, per Charleton J, at [11].

${ }^{33} \mathrm{https}$ ://www.workplacerelations.ie/en/Publications Forms/Legislating for a World-

Class_Workplace_Relations_Service.pdf (accessed June 2 2016).

${ }^{34}$ See, for example, NERA's annual review for 2013 available at: https://www.workplacerelations.ie/en/newsmedia/Workplace Relations Notices/NERA Publishes_Annual Review for 2013.html (accessed June 2 2016).
} 
The "action" largely took place in the sphere of collective employment rights.

Somewhat ironically however, in the context of developments in other 'bail-out' countries,$^{35}$ developments largely resulted from decisions of the Irish superior courts. It has been noted that, by contrast, for example, with the Greek case, little in terms of labour law reform was demanded by the Irish MoU concluded with the Troika. ${ }^{36}$ The most significant requirement in this regard, was for the government to commission an independent review of the Registered Employment Agreement (REA) and Joint Labour Committee (JLC) arrangements, with terms of reference and follow-up actions to be agreed with the European Commission. This review was to be carried out in order to ensure there were no distortions of wage conditions across sectors associated with the presence of sectoral minimum wages in addition to the national minimum wage. The explanation for this light touch is relatively straightforward; Ireland's labour market (with its floor of minimum standards and its weak protection for collective bargaining) was already subject to extremely light regulation. Nonetheless, Ireland was still required to review one of the few areas of regulation that provided for collectively bargained standards and that allowed workers to benefit from collective representation without having to first "trigger" their rights. Achtsioglou and Doherty point out that what is significant "is the extent to which labour market regulation is to be "micro-managed" by the EU institutions; even in relatively 'neoliberal' Ireland". 37

\footnotetext{
${ }^{35}$ See, for example, Leonardo Costa, Nuno Ornelas Martins, and Francisca Guedes de Oliveira, "Portugal's Bailout and the Crisis of the European Union from a Capability Perspective" (2016) 40 Cambridge Journal of Economics (online); Deborah Zandstra, "The European Sovereign Debt Crisis and its Evolving Resolution" (2011) 6(3) Capital Markets Law Journal 285.

${ }^{36}$ Eftychia Achtsioglou and Michael Doherty, "There Must Be Some Way Out of Here...The Crisis, Labour Rights and Member States in the Eye of the Storm" (2014) 20(2) ELJ 219.

${ }^{37} \mathrm{Ibid}$, at 237.
} 


\section{(i) Sectoral Standards}

In any case, the Troika need not have been so concerned. The Irish High Court in 2011 declared that the legislation allowing the imposition of terms and conditions of employment by means of an ERO was unconstitutional. ${ }^{38}$ The Minister for Jobs, Enterprise and Innovation moved swiftly to pledge new legislation to re-establish, with significant reforms, the ERO/REA systems; the result is the Industrial Relations (Amendment) Act 2012. The Act also reformed the procedures for REAs, in particular outlining detailed criteria by which the parties could claim to be "representative" before a registered collective agreement could be extended erga omnes. However, mere months after this legislation had been passed, the Supreme Court declared the section of the legislation establishing the REA system (Part III of the Industrial Relations Act 1946, which the 2012 Act purported to amend) to be also unconstitutional in McGowan \& Ors v The Labour Court \& Ors. ${ }^{39}$ The language used by the Supreme Court is worthy of comment. The Court notes that the provisions of part III appear "somewhat anomalous" today and give rise to the "prospect of burdensome restraints on competition for prospective employers and intrusive paternalism for prospective employees". ${ }^{40}$ In this regard, it should be pointed out that, far from being "anomalous", the erga omnes extension of sectoral collective

38 John Grace Fried Chicken Ltd \& Ors v Catering Joint Labour Committee \& Ors [2011] IEHC 277. For full discussion of this case see Michael Doherty, "Battered and Fried? Regulation of Working Conditions and Wage-Setting after the 'John Grace' Decision” (2013) 19 DULJ 97.

39 [2013] IESC 21.

${ }^{40}$ Ibid, per O' Donnell J, at [8]. 
agreements is a well-established feature of employment law systems across

Europe. ${ }^{41}$

\section{(iii) Trade Union Recognition}

Even before the crisis had begun to manifest, in February 2007, the Irish Supreme Court handed down its decision on the "right to bargain" legislation in Ryanair v The Labour Court. ${ }^{42}$ The Supreme Court was highly critical of the procedures adopted by the Labour Court in hearing claims under the legislation, for example in not requiring the identification of employees in dispute and not requiring such employees to give oral evidence. In a pointed rebuke, the Court criticised the Labour Court's "mindset", which, in interpreting the meaning of "collective bargaining" favoured the way particular expressions were used and particular activities were carried out by trade unions. ${ }^{43}$ The Court felt that it would not be appropriate for 'collective bargaining' in a non-unionised company to be equated (in terms of form and procedures adopted) with collective bargaining involving a trade union. The Supreme Court held that the term "collective bargaining negotiations" should be given simply an ordinary meaning and not any distinctive meaning as understood in trade union negotiations. Finally, the Court discussed the nature of a non-union internal bargaining unit, which could negotiate on behalf of employees. The Supreme Court decision did not set down precise rules or offer guidelines for the operation of a non-union internal bargaining

\footnotetext{
${ }^{41}$ See the (2002) 20 country review available at: http://www.eurofound.europa.eu/observatories/eurwork/comparative-information/collective-bargainingcoverage-and-extension-procedures (accessed June 2 2016).

42 [2007] 4 IR 199.

${ }^{43}$ See Maura Connolly, "Industrial Relations (Miscellaneous Provisions) Act 2004-Implications for industrial relations law and practice of the Supreme Court decision in Ryanair v Labour Court and IMPACT" (2007) 3 IELJ 37; Michael Doherty, "Union Sundown? The Future of Collective Representation Rights in Irish Law" (2007) 4 IELJ 96.
} 
unit, but the judgment appeared to take the view that employers would be free to determine the form, structure and organisation of any internal collective bargaining units, as long as these have a degree of permanency and are not ad hoc. Doherty commented that this that this could mean that, were an employer to set up such a unit, it could presumably decide on issues such as how employees would be elected or chosen to be members, the remit of the unit, the terms of office of its members, and the rules and procedures of its operation. ${ }^{44}$ The decision, as noted, was handed down in early 2007. As the crisis progressed, it became apparent that the Act's procedures had become much less attractive to trade unions; the number of claims under the legislation dropped precipitously to the extent there were no Labour Court hearings dealing with the Acts at all in 2009. ${ }^{45}$

\section{(iii) National Bargaining}

The influence of the Troika in terms of the fate of national bargaining ("social partnership") was more overt. Initially, once the crisis hit, the social partners sought to continue the social partnership process, negotiating an 'interim wage agreement' in $2008 .{ }^{46}$ However, as the economic and employment situation rapidly deteriorated, and an attempt to renegotiate the 2008 deal failed, the government unilaterally introduced an emergency budget, introducing pay cuts for all public servants. Attempts to negotiate a new pact continued throughout 2009 and, in December, appeared to be on the verge of successful conclusion. However, a last minute revolt by government deputies over aspects of the deal relating to public sector reform led

\footnotetext{
${ }^{44}$ Doherty, (2009), n 21, at 394.

45 Ibid, at 395.

${ }^{46}$ O’Kelly (2010), n 28.
} 
to the government withdrawing, and the effective end of the Irish social partnership process. $^{47}$

Reform of employment relations in the public sector was one of the key elements in addressing the crisis in Ireland prescribed by the Troika. Many of the broad parameters of the response were set out in the National Recovery Plan 20112014,48 these are subsequently repeated, modified and monitored in the successive MoUs with the Troika. Reductions in public expenditure were to be achieved, in part by the reduction in numbers of public servants in the order of approximately 25,000 , and by the generation of significant savings through the reform of work practices in the public sector. Compulsory redundancies were avoided; arguably, the main trade union success in the negotiations of the three public service agreements since 2010 , the "Croke Park", "Haddington Road" and "Lansdowne Road" agreements. ${ }^{49}$ Nevertheless, Ireland's public sector was dramatically reduced in size at a time when demands on core public services (in health, education and, particularly in the context of high unemployment, social security and welfare) were increasing. However, it is the manner in which the reforms have been implemented that may have more lasting effects. McDonagh and Dundon have pointed out that "the abandonment of social partnership" was, arguably, "central to the government's strategy of dealing with the crisis". ${ }^{50}$ In 2013, the government announced that it wished to re-negotiate the terms of the 2010 Public Service Agreement (“Croke Park"), which still had at least one year to run. The manner of the "negotiation" is noteworthy. ${ }^{51}$ The first attempt to re-

\footnotetext{
${ }^{47}$ Michael Doherty, "Can the Patient Survive the Cure? Irish Labour Law in the Austerity Era" (2014) (5) European Labour Law Journal 82.

${ }^{48} \mathrm{http}: / /$ www.budget.gov.ie/The\%20National\%20Recovery\%20Plan\%202011-2014.pdf (accessed June 2 2016).

49 http://www.per.gov.ie/en/public-service-reform/.

50 Terence McDonagh and Tony Dundon, "Thatcherism Delayed? The Irish Crisis and Paradox of Social Partnership" (2010) 41 Industrial Relations Journal 544, at 558.

${ }^{51}$ Doherty (2014), n 47.
} 
negotiate produced a deal ("Croke Park Two") that was rejected by public sector union members following a ballot. Following another round of negotiations, modified proposals were presented to union members in the "Haddington Road Agreement". In a remarkable intervention, the government published, at the same time as the Agreement emerged, what was subsequently enacted as the Financial Emergency Measures in the Public Interest Act (FEMPI) 2013. This legislation provided that members of unions that refused to sign up to the "Haddington Road Agreement" would simply have their pay cut, and terms and conditions of employment altered, by legislation. The protections of the Agreement (in relation to no compulsory redundancies, for example) would not apply to the members of such unions. Accord, on this occasion, was not to be left to chance!

\section{After the Flood}

At the time of writing (June 2016), Ireland has exited the EU-IMF programme, unemployment has declined to under $8 \%$ (a seven year low), the annual GDP growth rate, in early 2016 , was over $9 \%$, and the public finances are comfortably meeting EU budgetary targets. ${ }^{52}$ Late-2015 saw the enactment of two hugely significant pieces of employment legislation. The next section moves to look at where labour law in Ireland is heading "post-austerity".

\footnotetext{
${ }^{52}$ Figures from the Central Statistics Office (www.cso.ie; accessed June 2 2016).
} 


\section{Resurrection...? (2015- )}

\section{Individual Rights}

A notable feature of the nascent economic recovery inlreland has been how quickly discourse has moved from a relentless focus on unemployment to a focus on lowpay and the working conditions of low-pay workers. The government has established a Low Pay Commission under the National Minimum Wage (Low Pay Commission) Act 2015, which, under section 6, is empowered to make recommendations to the Minister designed to set a minimum wage that is fair and sustainable, and when appropriate, is adjusted incrementally, and that, over time, is progressively increased to assist as many low-paid workers as is reasonably practicable without creating significant adverse consequences for employment or competitiveness. The Commission's first report recommended an increase of $50 \mathrm{c}$ in the national minimum wage..$^{53}$ In the context of a high-profile dispute at retailer Dunnes Stores, the issue of "zero-hour" contracts/ low hour contracts was the subject of a report published by the Department of Jobs, Enterprise and Innovation in November 2015, which made a number of recommendations for legislative action to protect workers on so-called "if and when" contracts (where workers are not contractually required to make themselves available for work, but are dependent on a particular employer).${ }^{54}$ In both cases, the legislative measures enacted, or proposed, may well be seen as welcome employment protections, but operate firmly within the traditional floor of rights model.

\footnotetext{
${ }^{53} \mathrm{http}: / /$ www.lowpaycommission.ie/Publications/National-Minimum-Wage-/ (accesed June 2 2016).

${ }^{54} \mathrm{https} / / / \mathrm{www} . d j e i . i e / e n / N e w s-A n d-E v e n t s / D e p a r t m e n t-N e w s / 2015 /$ November/03112015a.html (accessed June 2 2016).
} 
Perhaps more significantly, the long-awaited reform of the employment tribunal system finally saw the legislative light of day in the form of the Workplace Relations Act 2015. The Act establishes the Workplace Relations Commission (WRC), which subsumes all of the existing employment tribunals, including the labour inspectorate (formerly NERA) ensuring that one single body deals with all employment claims at first instance. ${ }^{55} \mathrm{~A}$ reformed Labour Court will now hear all appeals. ${ }^{56}$ The WRC has a statutory duty, under section 11 of the 2015 Act to ensure high standards of compliance with employment legislation and equally high standards in the conduct of industrial relations generally. This is not the place to undertake a thorough review of the legislation. ${ }^{57}$ It is sufficient to comment that, whilst the simplification of the system is long overdue, it remains to be seen whether the Act does provide an effective system of individual dispute resolution. Concerns may include that the first instance hearing will be in camera, that it will be before a single Adjudication Officer (who does not need to be a lawyer), and that the Act abolishes, at first instance, the tripartite "industrial jury" model. ${ }^{58}$

\section{Collective Rights}

A further piece of hugely significant legislation, this time relating to collective employment rights, was passed in late-2015; the Industrial Relations (Amendment) Act 2015. Once again, this paper does not seek to be a comprehensive review and

\footnotetext{
${ }^{55}$ Workplace Relations Act 2015, section 41.

${ }^{56}$ Workplace Relations Act 2015, section 44.

${ }^{57}$ See, for example, Marguerite Bolger, "The Workplace Relations Bill: World-class or Legally Flawed?" (2015) 12(1) IELJ 21; Karen Killalea, "Workplace Relations Act - A Revolution in Irish Employment Law" (2015) 24 IRN 23.

${ }^{58}$ It should be noted that appeals to the Labour Court will be heard in public, before a tripartite Court; Workplace Relations Act 2015, section 44.
} 
analysis of the legislation, but confines itself to point out some of its notable features, as they are relevant to the argument in the final section.

\section{(i) Sectoral Standards}

First, the Act re-establishes the Registered Employment Agreement (REA) system. It sets out the factors which must be taken into account by the Labour Court where one or more trade unions on the one hand, and an individual employer or group of employers on the other, wish to register an agreement. It must be "normal and desirable practice or expedient" to have a separate agreement for that class, type or group of workers. ${ }^{59}$ Applicants must be "substantially representative" of the workers. ${ }^{60}$ This is not defined in the Act, but the Court must take into consideration the number of workers represented by the trade union(s), that are employed by the employer(s), specified in the agreement. REAs must promote "harmonious relations" and avoid "industrial unrest" ${ }^{61}$ Crucially, however, Registered Employment Agreements will now only bind the workers and employer, or employers, that are parties to the agreement; there is no sectoral erga omnes extension.

In terms of Joint Labour Committees (JLCs), the conditions for these had been set out in the Industrial Relations (Amendment) Act 2012, passed as a response to the John Grace decision. The review of REAs/JLCs ordered by the Troika was completed and recommended reform, rather than abolition, of the system. ${ }^{62}$ The recommended number of JLCs was reduced to seven sectors: hotels,

\footnotetext{
${ }^{59}$ Industrial Relations (Amendment) Act 2015, section 8(3)(c).

${ }^{60}$ Industrial Relations (Amendment) Act 2015, section 8(2)(b).

${ }^{61}$ Industrial Relations (Amendment) Act 2015, section 8(3)(f).

${ }^{62}$ Kevin Duffy and Frank Walsh, "Report of Independent Review of Employment Regulation Orders and Registered Employment Agreement Wage Setting Mechanisms" (2011) (available at
} 
catering, retail grocery; hairdressing; agricultural workers; security; contract cleaning. At the time of writing, JLCs have re-established sectoral terms and conditions of employment in the security and contract cleaning sectors only; 63 employers in the other sectors (and, particularly, in the hotels sector), have been unwilling to participate in the new system.

Perhaps anticipating precisely such opposition, the Industrial Relations (Amendment) Act 2015 provides for a new form of universally applicable sectoral terms and conditions in the form of Sectoral Employment Orders (SEOs). Applications to establish such an Order may be made by a trade union (alone or jointly with an employer organisation) where the union is "substantially representative of the workers of the particular class, type or group in the economic sector" concerned. ${ }^{64}$ It must be "normal, desirable or expedient' to have a SEO for pay, sick pay, and pension schemes in the sector concerned, taking into account the need for "harmonious relations" in the sector. ${ }^{65}$ In coming to a decision on whether to recommend an Order to the Minister, the Labour Court must take into account a range of factors, including the potential impact on competitiveness in the sector, and the binding nature of the SEO on all workers and employers. ${ }^{66}$ The Court must be satisfied that the making of an order is necessary in order to promote high standards of training, and to ensure fair and sustainable rates of remuneration, within the

https://jiei.ie/en/Publications/Independent-Review-of-ERO-and-REA-Wage-Setting-Mechanisms.html; accessed June 2 2016).

${ }^{63}$ SI 417/2015 Employment Regulation Order (Security Industry Joint Labour Committee): SI 418/2015

Employment Regulation Order (Contract Cleaning Joint Labour Committee) 2015.

${ }^{64}$ Industrial Relations (Amendment) Act 2015, section 14(2)(a).

${ }^{65}$ Industrial Relations (Amendment) Act 2015, section 15(1).

${ }^{66}$ Industrial Relations (Amendment) Act 2015, section 16(2). 
sector. ${ }^{67}$ An employer in a sector where an SEO operates may plead 'inability to pay' (up to a maximum period of 24 months). ${ }^{68}$

\section{(ii) Trade Union Recognition}

The Act also, almost a decade on from the decision in Ryanair, amends the 'right to bargain' legislation, the Industrial Relations (Amendment) Acts 2001-2004. A new definition of "collective bargaining" is outlined:

"collective bargaining comprises voluntary engagements or negotiations between any employer or employers' organisation on the one hand and a trade union of workers or excepted body to which this Act applies on the other, with the object of reaching agreement regarding working conditions or terms of employment, or non-employment, of workers". 69

The provisions of the Act, therefore, apply only where such bargaining does not occur in an organisation, be that with a trade union, or an "excepted body", which is defined as:

"a body which is independent and not under the domination and control of an employer or trade union of employers, all the members of which body are employed by the same employer and which carries on engagements or negotiations with the object of reaching agreement regarding the wages or

\footnotetext{
${ }^{67}$ Industrial Relations (Amendment) Act 2015, section 16(4).

${ }^{68}$ Industrial Relations (Amendment) Act 2015, section 21.

${ }^{69}$ Industrial Relations (Amendment) Act 2001, section 1A, as inserted by the Industrial Relations Amendment Act 2015, section 27.
} 
other conditions of employment of its own members (but of no other employees" ${ }^{70}$

In an attempt to deal with a frequent criticism of the Ryanair judgment (that the Supreme Court dicta had suggested something very close to a "company union" could satisfy the requirements), ${ }^{71}$ the Labour Court is now required to assess excepted bodies to ensure their independence with regard to: the manner and frequency of the election of employees, the financing or resourcing that exceeds minimum logistical support provided by the employer, the length of time a body has been in existence, and any prior collective bargaining with the employer. ${ }^{72}$

Previously, under the 2001-2004 Acts, a union could submit a claim in respect of any number of its members; in some cases, the unions involved pursued a claim where they declared to have a considerable existing presence, whilst in others claims were taken on behalf of a handful of employees only. ${ }^{73}$ The new legislation requires that claims can only be taken where the number of workers party to the dispute is not insignificant, having regard to the total number of workers employed by the employer concerned in the grade, group or category to which the dispute refers, and by reference to the total number of workers employed by the employer in the group referring the dispute, relative to the total employed by the employer. ${ }^{74}$

\footnotetext{
${ }^{70}$ Industrial Relations (Amendment) Act 2001, section 1B, as inserted by the Industrial Relations Amendment Act 2015, section 27.

${ }^{71}$ Doherty (2009), n 21.

${ }^{72}$ Industrial Relations (Amendment) Act 2001, section 2(10), as inserted by the Industrial Relations Amendment Act 2015, section 28.

${ }^{73}$ Michael Doherty, “'When You Ain't Got Nothin', You Got Nothin' to Lose.... Union Recognition Laws, Voluntarism and the Anglo Model" (2013) 42 ILJ 369.

${ }^{74}$ Industrial Relations (Amendment) Act 2001, sections 2(3)-(6), as inserted by the Industrial Relations Amendment Act 2015, section 28.
} 
As noted above, significant concerns arose following the Ryanair decision around identifying the numbers and identities of individual union members taking a claim under the legislation. ${ }^{75}$ The new legislation now allows for the making of a "statutory declaration" by a chief officer of a trade union specifying the number of members it has which are employed by the employer and their period of membership to the satisfaction of the Labour Court, but the identities of individual members will remain confidential. ${ }^{76}$

In making a recommendation on terms and conditions of employment, the Labour Court must now consider the "totality" of the remuneration and conditions of employment of the workers concerned, by reference to the remuneration and conditions of employment of comparable workers, explicitly including those working in non-unionised workplaces. ${ }^{77}$

Finally, the 2015 Acts includes new anti-victimisation provisions by providing for interim relief pending determination of a claim for unfair dismissal, where a worker alleges the dismissal results from seeking to exercise rights under the legislation. ${ }^{78}$

\section{(iii) National Bargaining}

\footnotetext{
${ }^{75}$ Doherty (2009), n 21.

${ }^{76}$ Industrial Relations (Amendment) Act 2001, section 2A(1), as inserted by the Industrial Relations Amendment Act 2015, section 29.

${ }^{77}$ Industrial Relations (Amendment) Act 2001, section 5(1), as amended by the Industrial Relations Amendment Act 2015, section 30; Industrial Relations (Amendment) Act 2001, section 5(4)), as inserted by the Industrial Relations Amendment Act 2015, section 30.

${ }^{78}$ Industrial Relations (Amendment) Act 2001, section 11A, as inserted by the Industrial Relations Amendment Act 2015, section 4. This is a novel provision under Irish law; dismissal law usually kicks-in after the dismissal has occurred. A similar provision can be found in relation to "whistle-blowers" in the Protected Disclosures Act 2014 (schedule 1)
} 
There has been no return to the centralised, social partnership-style bargaining of the 1987-2007 vintage. In July 2015, the government hosted a two-day "National Economic Dialogue" session, designed to facilitate an open and inclusive exchange on the competing economic and social priorities relevant for the preparation of that year's Budget. Representatives of community, voluntary and environmental groups as well the political opposition, business, unions, research institutes, the academic community, and the diaspora attended. Centralised bargaining continued in the Public Sector, with the conclusion of the "Lansdowne Road Agreement" in 2015. In the private sector, voluntary collective bargaining has returned to enterprise level. 


\section{But These Visions of Johanna... ${ }^{79}$}

So, after almost a decade of austerity, high unemployment, mass emigration, and social discord, Ireland is slowly emerging from the ruins of the crash. What does the labour law story sketched above tell us, and how does it fit with the wider European narrative?

The continuity of the Anglo-Saxon model has been noted. Individual employment law in Ireland remains firmly rooted in a floor of rights_model, with amendments (while positive in terms of the Low Pay Commission and proposals on "if and when" contracts) amounting to little more than tinkering around the edges. The Troika was notably unconcerned with Ireland's moves to increase minimum wage levels; it was only in those very limited areas of labour market intervention where (higher) sectoral standards of employment could be applied, via a process of bargaining that involved worker representatives, that intervention occurred. It has been pointed out that this is perfectly consistent with general trends under EU law, which also militate against collective approaches to labour market regulation, ${ }^{80}$ notably in the 'Laval Quartet' (Laval, Viking, Rüffert and Luxembourg), ${ }^{81}$ and more recently in decisions like Alemo-Herron. ${ }^{82}$ I would argue similarly that, in the area of compliance with labour law, Irish law is also moving in a manner consistent with European trends. Employment rights are largely to be monitored and enforced by the State labour inspectorate (and the possibility of criminal prosecution remains a

\footnotetext{
79 'We sit here stranded, though we're all doin' our best to deny it... jewels and binoculars hang from the head of the mule, but these visions of Johanna, they make it all seem so cruel' (Bob Dylan, Visions of Johanna, 1966).

${ }^{80}$ Doherty (2013), n 16.

${ }^{81}$ Case $\boldsymbol{C - 3 4 1 / 0 5}$ Laval v Svenska Byggnadsarbetareförbundet [2007] ECR I-11767; Case C-438/05 International Transport Workers' Federation and Finnish Seamen's Union v Viking Line ABP [2007] ECR I10779; Case C-346/06 Rüffert v Land Niedersachsen [2008] ECR I-1989; and Case C-319/06 Commission v Luxembourg [2006] ECR 1-8673.

${ }^{82}$ Case C-426/11 Alemo-Herron v Parkwood Leisure Ltd. [2014] 1 CMLR 21.
} 
feature). There are two, related, points he re. First, one consequence of austerity has been a reduction in resourcing of all State agencies, compromising their ability to adequately carry out their functions. Secondly, at EU level, what labour market legislation we have seen in recent years has been quite focused on enforcement and procedural reform of existing law (e.g. the Posted Workers Enforcement Directive; the Directive on vindicating free movement of citizens' rights). ${ }^{83}$ This is not to argue that such legislation is necessarily unwelcome. It is to point out, first, the narrow vision of labour law reform coming from the EU, and, secondly, to note that, whilst there is an acknowledgement in such legislation of the role and importance of social partner activities in ensuring the vindication of employment rights, there is little of substance that would seem to make these more likely, certainly in countries such as Ireland.

The discussion of reform of the employment tribunal system, although hugely significant to Irish workers and employers, may seem somewhat parochial. However, the broader significance echoes the points made by Novitz in her paper to [THE TCD SYMPOSIUM]. The reforms are all aimed at resolving disputes as close to the workplace as possible (via interventions by WRC "early resolution" officers, mediation, more active case management by Adjudication Officers, etc). This is admirable. It does lead to concerns, however, given the lack of support for individual workers at workplace level. Trade union presence is greatly diminished; the reasons for this are complex, and multi-faceted, but, certainly, a lack of legislative support for

\footnotetext{
${ }^{83}$ Directive 2014/67/EU of the European Parliament and of the Council of 15 May 2014 on the enforcement of Directive 96/71/EC concerning the posting of workers in the framework of the provision of services and amending Regulation (EU) No 1024/2012 on administrative cooperation through the Internal Market Information System ('the IMI Regulation'), OJ L159/11; Directive 2014/54/EU of the European Parliament and of the Council of 16 April 2014 on measures facilitating the exercise of rights conferred on workers in the context of freedom of movement for workers, OJ L128/8.
} 
trade union representative functions is one. Other, non-union, employee representative structures are virtually non-existent in Ireland; there is no Works Council system, and the weak implementation of information and consultation obligations under the 2002 Directive has rendered that legislation largely useless. ${ }^{84}$ "Excepted bodies" are not widely in existence and, where they are, seem to be of the order of the body in Ryanair. The amendments in the 2015 Act may help guard against "company unions", but they are unlikely to spur the establishment of genuinely independent, non-union employee representative bodies (and neither is that the intention of the Act). Thus, there is a real danger, in the absence of adequate workplace level advocacy, support, and information structures, which are genuinely independent, of a drift to a US model of individual dispute resolution; notably, only workers with the means to access legal representation will be able to somewhat balance the scales of power. ${ }^{85}$

The link between the vindication and enforcement of individual rights, and the role of collective representation, is important. Again, developments in Ireland in terms of collective employment law chime clearly with those at the level of the EU. Reforms of the sectoral standard-setting mechanisms are very much to be welcomed; the government could have taken the option of simply abandoning these, given the views of the domestic judiciary, and the implicit direction of the Troika. However, what has emerged is undoubtedly a truncated form of collective bargaining. Sectoral Employment Orders may now be applied for by a trade union alone; clearly this is not "bargaining" at all, but a mechanism for the unilateral

\footnotetext{
${ }^{84}$ Michael Doherty, “It's Good to Talk...Isn't It? Legislating for Information and Consultation in the Irish Workplace" (2008) 30 DULJ 120.

85 A.J.S Colvin, “American Workplace Dispute Resolution in the Individual Rights Era" (2012) Cornell University: http://digitalcommons.ilr.cornell.edu/articles/833/ (accessed June 2 2016).
} 
imposition of sectoral standards by the (admittedly tri-partite) Labour Court, and subject to Ministerial veto. ${ }^{86}$ This is likely to be an antagonistic process, where, undoubtedly, legal challenges will emerge. What we see, therefore, is a movement away from state-supported sectoral bargaining, to a system heavily reliant on statesanctioned legal standard-setting. In Ewing's terms, there is an ever greater emphasis on the "representative" function of trade unions, rather than the "regulatory" function of collective bargaining. ${ }^{87}$

We see this too in relation to the "right to bargain" legislation. The manner in which that legislation came to be applied by the Labour Court arguably began to veer towards the legislation performing a more explicit regulatory and public function (in Ewing's terms) than initially appeared likely. In a number of cases, the Court made recommendations on remuneration based on pay norms in the given industry. In Bank of Ireland ${ }^{88}$ the Court pointed out:

"The powers which are given to the Court by the Act are a far-reaching departure from the normal approach to the resolution of industrial relations disputes. They provided, in effect, that the Court may arbitrate in a dispute on the unilateral application of one party and in circumstances where the other party may not consent to the process. It seems to the Court that, having regard to the voluntary nature of our industrial relations system, such an intervention is only appropriate where it is necessary in order to provide protection to workers whose terms and conditions of employment, when viewed in their totality, are significantly out of line with appropriate standards".

\footnotetext{
${ }^{86}$ Industrial Relations Amendment Act 2015, section 17.

${ }^{87}$ K.D. Ewing, "The Function of Trade Unions" (2005) 34 ILJ 1.

${ }^{88}$ Case LCR17745 issued on 28/01/2004.
} 
Thus, the Court sought to introduce the idea of the "model employer"; by effectively benchmarking respondent companies against others in the sector. ${ }^{89}$ This can be seen in Fournier Laboratories, ${ }^{90}$ where the Court found that the company's pay determination system was out of line with accepted standards in that it was based solely on performance-assessment, rather than by reference to a basic 'rate for the job', the predominant practice in the sector. Similarly, in Cooley Distillery ${ }^{91}$ the Court accepted pay rates agreed by the union (through collective bargaining) with other employments both locally and nationally as indicative of the industry norm. It recommended the respondent increase its pay rates to this more "appropriate standard". Therefore, where companies fall below the general, prevailing industry standards (as located by the Court) they were told to raise standards to that level (frequently identified as those set down by national pay agreements then in existence). Doherty has noted that this approach of legally mandating the payment of prevailing industry rates (generally reached through employer-union engagement) rather than statutory minima had clear implications for the controversial debate set in motion by the Court of Justice in the 'Laval Quartet'. ${ }^{22}$ The striking down of the legislation in Ryanair, and the resulting amendments in 2015 , clearly row back from this, with the emphasis being on "counting" union members (the right to be represented by a union under this legislation is only available where an individual member can argue a not insignificant number of colleagues are union members, and also in dispute), and heavily circumscribing the Labour Court's benchmarking role.

\footnotetext{
${ }^{89}$ Doherty (2013), n 73.

${ }^{90}$ Case LCR18582 issued on 24/05/2006.

${ }^{91}$ Case LCR17908 issued on 19/07/2004.

92 Doherty (2009), n 21.
} 
Lastly, as noted above, the approach to public sector bargaining has redefined traditional understandings of labour relations "negotiation"; the government was happy to engage in long, and difficult, negotiations with the public sector trade unions in order to reach an agreement. It was not willing, however, to leave the outcome to be subject to the vagaries of union democracy. Public sector union members were simply issued an ultimatum; accept the agreement or face legislation mandating worse terms and conditions of employment. Pay across the public service is now increasingly being determined by central government and, in particular, by the Department of Public Expenditure and Reform (DPER). Indeed, recent research reports that this Department has effectively become that which determines pay and general employment terms and conditions for all areas of the Irish public service. ${ }^{93}$ It seems the individual departments and public sector management in sectors such as Health and Education are reduced to merely complying with the demands of DPER.

This analysis of the Irish response to the crisis, shaped and approved by the Troika, (including, of course, the European Commission) has emphasised measures directed towards reducing the influence of trade unions on labour market regulation and reducing the scope for collectively bargained employment standards, in favour of legally binding minima. The role of the social partners (and, especially, the trade unions) in enforcing and policing employment standards has also been reduced. In the heavily unionised public sector, the move has been to downgrade terms and conditions of employment, particularly for new entrants, and to move away from a

\footnotetext{
${ }^{93}$ Aurora Trif and Michael Doherty, The Impact of the Crisis on Collective Bargaining in Romania and Ireland (paper presented at the Industrial Relations in Europe (IREC) Annual Conference, Bucharest, Romania, September 2013); Michael Doherty and Aurora Trif, Horses for Courses? Trade Union Responses to the Crisis in Romania and Ireland in Ireland and Romania (paper presented at the Industrial Relations in Europe (IREC) Annual Conference, Dublin, Ireland, September 2014).
} 
consensual, partnership approach to collective bargaining. The move is clearly towards setting legislative standards, which seem to operate as a "ceiling" rather than a "floor"; in the public sector, members of trade unions that do not accept the government's "negotiation" position will simply have terms and conditions set by law.

As noted, developments in Ireland seem perfectly consistent with recent jurisprudence of the Court of Justice. Barnard has noted that this case law reflects the "single market approach" of the CJEU, which sees the application of national labour law by a host state as a barrier to the provision of services under Article 56TFEU and therefore presumptively unlawful. This contrasts with the "labour law" perspective traditionally adopted by Ireland, the UK, and a number of other Member States, which seeks to apply national labour rules to all those working in the national territory in the name of equality, fairness and, crucially, good industrial relations ${ }^{94}$ and which relies significantly on monitoring by the social partners.

Turning from the jurisprudence of the Court, a key response to the crisis, in addition to the terms of the MoUs agreed with the 'programme countries', has been the establishment of a strict economic governance package for all Eurozone countries. ${ }^{95}$ Notwithstanding the limited competence in the sphere of labour law afforded to the EU legislator in the Treaties (see Articles 151 and 153 TFEU), the Euro Plus Pact is quite clear about what Member States must do in order to "foster competitiveness": 96

\footnotetext{
${ }^{94}$ Catherine Barnard, "The UK and Posted Workers: The Effect of Commission v Luxembourg on the Territorial Application of British Labour Law" (2009) 38 ILJ 123.

${ }^{95}$ Eleni Balamoti, "Evaluating the New Rules of EU Economic Governance in Times of Crisis" (2014) 5 European Labour Law Journal 97.

${ }^{96} \mathrm{http}$ ://www.consilium.europa.eu/uedocs/cms_data/docs/pressdata/en/ec/120296.pdf; emphasis added by author (accessed June 2 2016).
} 
- Review the wage setting arrangements, and, where necessary, the degree of centralisation in the bargaining process, and the indexation mechanisms, while maintaining the autonomy of the social partners in the collective bargaining process;

- ensure that wages settlements in the public sector support the competitiveness efforts in the private sector (bearing in mind the important signalling effect of public sector wages).

The "Country-Specific Recommendations" (CSRs) now issued to Member States have become ever more intrusive in the area of labour law, focussing increasingly on wage-setting mechanisms. ${ }^{97}$ Bekker and Klosse note that at least five co-ordination mechanisms now support CSRs ranging from soft law policy co-ordination (the Euro Plus Pact and Europe 2020) to measures which combine soft law and hard law mechanisms (the Stability and Growth Pact and the Macro-economic Imbalances Procedure). ${ }^{98}$ Thus, as in Ireland, where the Department of Public Expenditure and Reform dominates policy actions in relation to labour law, we see increasingly EU employment policy being directed by the Ecofin council, made up of the economics and finance ministers (and relevant EU Commissioners) of the Member States. The crisis has also seen policy responses being driven by inter-governmentalism; there

\footnotetext{
${ }^{97}$ Sonja Bekker and Saskia Klosse, "Changing Legal Context of Employment Policy Coordination: How do Social Policy Issues Fare after the Crisis?" (2013) 5 European Labour Law Journal 6.

${ }^{98}$ Sonja Bekker and Saskia Klosse, "EU Governance of Economic and Social Policies: Chances and Challenges for Social Europe" (2013) European Journal of Social Law 103. CSRs were originally formulated in the context of the (soft law) Open Method of Co-ordination (OMC).
} 
have been, for example, no fundamental attempts to reform EU social legislation and no intervention from the Court of Justice on the impact of the economic measures demanded by the Troika (unlike clear interventions from the ILO and the Council of Europe). ${ }^{99}$ Equally, social dialogue seems to be in abeyance. Instead, in the Eurozone, where currency devaluation is not an option, we see the "burden of adjustment" falling on national labour law systems (with the aim always to reduce their "distorting effects"), which now increasingly compete with one another. ${ }^{100}$

${ }^{99}$ In terms of ILO obligations, see, for example, Case 2820 in the 365th Report of the Committee on Freedom of Association (November 2012), 784-2003 (available at: www.ilo.org/gb/GBSessions/GB316/ins/WCMS 193260/lang--en/index.htm, accessed June 2 2016). The European Committee for Social Rights (ECSR), the main supervisory body for the Council of Europe's Social Charter, in its Conclusions for 2013, found 180 cases of violations of the Charter concerning health, social security and social protection. Programme countries Greece and Romania received a particularly high number of negative conclusions; http://www.coe.int/en/web/turin-european-social-charter/case-law (accessed June 22016 ). 100 Wolfgang Däubler, "Labour Law and Competition" in Marc Rigaux, Jan Buelens and Amanda Latinne eds, From Labour Law to Social Competition Law? (Intersentia, 2014) at 57. 


\section{Conclusions: Gimme Hope Jo'anna?}

The policy responses outlined above, however, were and are political choices; and political choices can be challenged and modified. It seems clear that a narrow focus on legislative floors of rights, which must be vindicated by individual workers in employment tribunals, and monitored and enforced by under resourced labour inspectorates, is inadequate to offer genuine protection to workers. The move towards reducing the scope for collectively bargained standards and social partner monitoring thereof, and towards the abandonment of social dialogue, in favour of regulation obsessed with financial monitoring and dominated by economic discourse must be reversed in order to achieve the Treaty aims of a "social market economy". ${ }^{101}$ It may be, as some argue, that labour law can only ever provide a marginal correction to the worst excesses of (labour) market liberalisation and cannot, without more, modify the "bases and principles of the market's existence and functioning". ${ }^{102}$ However, progressive legal change can be a start.

In this regard, let me cite three areas where reform could help. First, the new public procurement directives explicitly require Member States to take appropriate measures to ensure that, in the performance of public contracts, economic operators comply with applicable obligations in the fields of environmental, social and labour law established by Union law, national law, collective agreements' and various ILO conventions (Article 18 of Directive 2014/24). ${ }^{103}$ A robust transposition and operation

\footnotetext{
${ }^{101}$ Dagmar Schiek et al, EU Social and Labour Rights and EU Internal Market Law (2015), Study for the European Employment Committee,

http://www.europarl.europa.eu/thinktank/en/document.html?reference=IPOL_STU(2015)563457 (accessed June 2 2016).

${ }^{102}$ Marc Rigaux, 'Labour Law or Social Competition Law? The Right to Dignity of Working People Questioned (Once Again)' in in Marc Rigaux, Jan Buelens and Amanda Latinne eds, From Labour Law to Social Competition Law? (Intersentia, 2014) at 11.

${ }^{103}$ Directive 2014/24/EU of the European Parliament and of the Council of 26 February 2014 on public procurement and repealing Directive 2004/18/EC, OJ L94/65; Directive 2014/25/EU of the European Parliament
} 
of the Directives at Member State level, and protection by the Court for the operation of "social clauses", would enable Member States to use taxpayer's money to further "decent work". 104

Secondly, the long-mooted recast of the information and consultation directives may provide an impetus for Member States (especially those with no general, permanent and statutory system of information and consultation of employees, nor a general, permanent and statutory system or of employee representation at the workplace) to look again at workplace employee representation structures, particularly where trade unions are absent. ${ }^{105}$ More broadly, a commitment by the new European commission to revitalise EU social dialogue processes would also send a positive signal to Member States

Thirdly, in the context of the Commission's programme to modernise company law and enhance corporate governance, ${ }^{106}$ looking again at board-level employee representation, and how the provisions in respect of this can be strengthened, would provide not only the possibility of stronger worker protection, but also some evidence of lesson-learning on the part of EU and national elites to present to a general populace which is increasingly cynical and angry following the corporate and regulatory failures leading to, and in some cases prolonging, the crisis.

and of the Council of 26 February 2014 on procurement by entities operating in the water, energy, transport and postal services sectors and repealing Directive 2004/17/EC, OJ L94/243.

${ }^{104} \mathrm{http}: / /$ www.ilo.org/global/topics/decent-work/lang--en/index.htm (accessed June 2 2016).

105 The European Commission began consultations with the EU-level Social Partners on this issue in April 2015; however, progress seems to have stalled http://ec.europa.eu/social/main.jsp?langId=en\&catId=89\&newsId=2192\&furtherNews=yes $106 \mathrm{http}$ ://ec.europa.eu/justice/civil/company-law/index_en.htm (accessed June 2 2016). 
